\title{
AUGMENTED REALITY IN INTERVENTION WITH PEOPLE WITH AUTISM SPECTRUM DISORDER: PROTOCOL ACTIVITIES
}

\author{
Alba Gilabert Cerdá, Eva García Albaladejo, Elena Pérez Vázquez, \\ Gonzalo Lorenzo Lledó, Asunción Lledó Carreres, \& Alejandro Lorenzo Lledó \\ Department of Evolutionary Psychology and Didactics, University of Alicante (Spain)
}

\begin{abstract}
Over the last few years, Augmented Reality (AR) has become one of the newest trends in technology due to its characteristics: ease of access to information on the world's reality and superimposition to the society of digital data in real time. Since the smartphone revolution, virtually everyone uses them continuously in their daily lives. These devices have a processor, GPS, screen, camera, microphone, etc., indispensable tools for AR experiences. Because of this, among other things, AR technology is constantly growing and captures the attention of many users around the world. Various studies show some relevant results in the intervention of Augmented Reality with students presenting with Autism Spectrum Disorder (ASD) in the acquisition of social skills that worked with parents, teachers and peers. Although ASD is highly heterogeneous, both in etiological issues and in the manifestations and evolution of symptoms at different stages of development, expression and presentation according to sex, age or co-morbidities presented; some of the impairments in the social skills of people with ASD have been described in various researches such as, for example, the presence of difficulties in intuitive comprehension in the social situation. Due to this, the objective of the work is to create a protocol of activities using Augmented Reality as a teaching methodology, to learn a specific routine that allows people with ASD, with verbal communicative behaviors and non-verbal communicative behaviors, to improve in the acquisition of communication and response to tasks and routines. The results obtained indicate that this protocol of activities that has been created allows people with ASD to obtain information from the world around them and respond safely to the demands of the environment. In addition, this protocol is characterized by following a favorable learning style for this disorder, as it studies how people with ASD obtain information about their environment.
\end{abstract}

Keywords: Augmented reality, ASD, social communication, social interaction, routines.

\section{Introduction}

To begin this study, it is necessary to first go back to the definition of Autism Spectrum Disorder, hereinafter ASD. In the first studies, Hobson (1995) stated that ASD is a rare and profound disorder, and it is really difficult to explain how autistic subjects are. Specifically, ASD encompasses a heterogeneous set of neurodevelopmental syndromes associated with deficits in social interaction, communication skills, mental flexibility, and sensory processing, as described by the American Psychiatric Association (2013).

Autism Spectrum Disorder is known in the early stages of development where the areas of communication, socialization and behavior are affected, causing a deficit in cognitive and emotional development (Cruz and Villanueva, 2020). Likewise, Villanueva and Brun (2008) specify that the environment of these people is also affected in a substantial way, generating suffering in the people who surround the social context, whether they are family members or professionals who take care of them.

Specifically, over the years, the care of people with Autism Spectrum Disorder has been related from a psychoanalytic, behavioral and therapeutic point of view, forgetting pedagogy and cognition from the field of Special Education (Badillo and Iguarán, 2020). The educational opportunities and the possibilities of success in life are marked by the pedagogical system of the 21 st century where the importance of educational transformation is evident: it is necessary to adopt measures that favor the learning of all students. As Miranda, Laz and Campuzano (2020) call it, it is found inclusive education, a modality that promotes better teaching opportunities. Along these lines, Booth and Ainscow (2002) stated that such education involves a set of processes aimed at eliminating or minimizing the barriers that stand 
in the way of student learning and participation in order to obtain the pedagogical achievement of all learners.

Therefore, it is the task of schools and pedagogy to understand and improve the teaching-learning processes of people with autism, adding technologies in the classroom that facilitate the inclusion of this population in the school. In this sense, teachers must be able to create work plans for their incorporation into the classes and, in this way, create a constructive use of new technologies. As indicates Villalustre (2020), the use of new technologies in the classroom requires a change in educational practices, becoming an important element of any educational and innovative process (Cabero, 2015).

Within the field of new technologies, it is found the so-called Augmented Reality (AR), which has reached a great boom in most sectors of society, including education. AR is understood by various authors as a technology that allows us to enjoy experiences in which virtual content is added to or superimposed on our environment, in real time (Estebanell, Ferrés, Cornellá and Codina, 2012; Reinoso, 2012). As it is quoted by López and Maquilón (2020) in a study by the company GARTNER on emerging technologies, it reflects that this is one of the technologies with the greatest expectations for the future and that in a range of five to ten years, it will be when it reaches its optimum level of adoption to reach the general public.

On this point, it has now been corroborated that the AR is a tool for the development of inclusive education (Marín-Díaz, 2018). However, as it is pointed out by Marín-Díaz and Sampedro-Requena (2020), it should be specified that this technology cannot be used in its entirety by those people who present visual, motor or psychological difficulties or who present high abilities, unlike the great viability of this tool with subjects who present ASD. Following Gilabert, Pérez, Lorenzo A., Lledó and Lorenzo G. (2019), numerous studies (El-Seoud, Halabi and Geroimenko, 2019; Vértiz, Pérez, Faustino, Vértiz, and Alain, 2019) show that the use of Augmented Reality is a fundamental tool to improve the understanding of academic interaction with ASD students and provides a new opportunity to address situations of Special Educational Needs that favor learning conditions.

\section{Objectives}

The main objective of this project is to promote the inclusion of Augmented Reality as an intervention tool in teaching-learning with people with Autism Spectrum Disorder. Therefore, a series of more specific objectives have been extracted to be reached: to carry out a search of articles that relate the participants with different styles of learning, with the Information and Communication Technologies (ICT) and, more specifically, with the AR; as well as, to design a protocol of activities in accordance with the characteristics of the ASD through the Augmented Reality.

\section{Method}

This project has been carried out thanks to the collaboration of all the members of the IncluTIC research group. Specifically, the method of this work is a qualitative study within an exploratory-descriptive level.

\subsection{Description of the context and participants}

Exploratory study has been carried out in a Centre for the Attention of Mentally Disabled People located in the city of Alicante. In particular, the participants are part of the residence unit.

Two people were involved in this study. Both subjects have a diagnosis of Autism Spectrum Disorder. Specifically, following their pedagogical reports based on the Diagnostic Statistical Manual of Mental Disorders (DSM-5) both present a level 2 ASD. In terms of age, one of them is 18 years old and the other participant is 21 years old. It should be noted that both cases 1 and 2 make use of verbal communication, although sometimes case 2 shows a negative behavior, refusing to communicate orally. More particularly, the two individuals have a moderate intellectual disability as well as a recognized overall disability of $70 \%$ in subject 1 and $75 \%$ in subject 2 . As far as the curricular field is concerned, the current level of competence of the cases is 0-3 years of preschool education.

\subsection{Design and process}

The following steps have been taken to carry out the process of finding information to complete the Augmented Reality-based activity protocol for people with ASD:

$1^{\text {st }}$. Search for articles dealing with activities related to the learning style of people with ASD. In these documents it has found that some of the characteristics such as the general treatment objectives of ASD proposed by Riviere (1998): to foster emotional well-being, to increase freedom, to promote 
personal autonomy, to increase communication possibilities, to develop cognitive skills, to improve the capacity of understanding human interactions and to expand learning skills.

$2^{\text {nd }}$. Search for articles on the use of new technologies as a tool for teaching-learning in students with ASD in which the benefits are provided as those cited by the authors Martinez, Pagan, Garcia S. and Máiquez (2014) who report that ICTs provide benefits for both teaching and learning of students with ASD, since they are characterized among other things by their versatility, flexibility and adaptability. Moreover, they are specifically adapted to the ASD student because they favor different learning rates and a greater individualization.

$3^{\text {rd }}$. Search for articles that expose the use of Augmented Reality in ASD intervention. To do this, it has been consulted the bibliometric analysis "Augmented Reality in the intervention of students with Autism Spectrum Disorder through scientific production" where researchers Gilabert, Perez, Lorenzo A., Lledó and Lorenzo G. (2019) show that in the educational field, there is an upward trend in the number of citations related to this topic as years go by and, therefore, it is evident that the use of Augmented Reality is a fundamental tool to improve the education of this group.

$4^{\text {th }}$. Analysis of the searches and data extraction for the realization of the activity protocol.

As it is observed, these steps include from the initial and wider step as it is the search of articles related to the learning style of the ASD people to the final and more concrete step as they are the documents that treat on the tool of AR for the students with this disorder and, the later analysis of all of them with the purpose of creating the protocol of activities to follow.

\section{Result}

The results of the investigation are described in detail below. Initially, the different phases to be followed to carry out the process of creating the AR-based activities that make up the activity protocol can be seen in Figure 1.

Figure 1. Phases of the activity protocol.

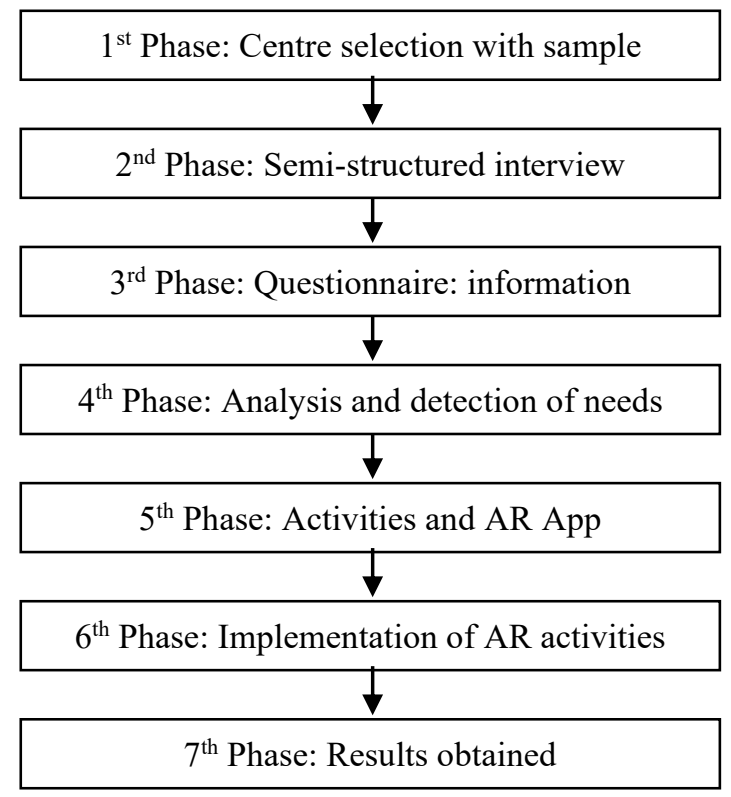

Below, each of the phases developed that make up the protocol of activities based on Augmented Reality for people with ASD are presented.

$1^{\text {st }}$ Phase. Firstly, we have selected a center in the city where there is a variety of population to be studied, in this case we have selected a center where there are numerous cases of people with Autism Spectrum Disorder, which is our field of application.

$2^{\text {nd }}$ Phase. Then, an appointment has been arranged with the management team of the center, in which the research team is authorized to hold a semi-structured interview with the team of professionals involved in the treatment of people with ASD (psychologists, therapists and sociologists). This is an extensive and open interview, in which pre-established questions are included, and a conversation is held regarding the cases of ASD found in the center, for the purpose of selecting those persons who are desired to form part of the exploratory research project. 
$3^{\text {rd }}$ Phase. Later, by means of a 10-item questionnaire, information was collected on the cases (age, ASD level, type of communication, level of curricular competence and degree of disability, among others). In addition, other types of questions were asked to the psychologists and therapists of the center in which they were asked about which habit or routine they considered essential to work on (hygiene, clothing, food, behavior, attention...) with the aim of proposing some activities that would affect the most important aspects to be dealt with.

$4^{\text {th }}$ Phase. Once the necessary information has been collected, the data obtained must be analyzed and the need in this population must be seen, on the basis of which the activities will be created using Augmented Reality as an intervention tool.

$5^{\text {th }}$ Phase. Next, the creation of the activities has to be started by choosing a specific topic and creating a series of sessions, in this case individual sessions so that the person can concentrate and fix his attention for as long as possible. The periods of concentration of the ASDs in which the attention is full are very short so the sessions should not exceed 30 minutes. Also, an Augmented Reality application should be selected to create the experiences for the intervention with ASD persons according to the different objectives to be worked on.

$6^{\text {th }}$ Phase. Subsequently, the implementation of the Augmented Reality activities has to be carried out. To do this, it is important to set the different sessions over time and prepare a space in which to carry out the exercises. It should be noted that the person responsible is the researcher although there should always be a person accompanying the participants due to their characteristics, at least in the first sessions.

$7^{\text {th }}$ Phase. In the last place, the results obtained after all the sessions must be evaluated in order to quantify the improvement produced in the subjects and to perfect the aspects that may have failed in the development of the application through the use of Augmented Reality.

\section{Conclusion}

The results of the research allow the following conclusions to be drawn. In general, it can be observed that ASD persons need to follow a routine with very ordered patterns in their teaching-learning process. Therefore, it is essential to create a protocol of activities to follow with these students in order to enhance, in an optimal way, their learning using, in addition, a tool that is adapted to their style of learning and capturing information such as Augmented Reality.

The type of session, timing and motivation are key to achieving adequate performance, but it is also necessary to follow a daily routine in the activities, that is, if you start with a dance at the beginning of the session you should do the same dance every day. People with this disorder like to anticipate what is going to be done and do not conceive a vision of the world in which the steps to be followed are not always the same.

It should also be noted that these activities should contain a center of interest in which the subject is motivated to learn through a playful way. In many occasions, ASDs feel some rejection when sitting in a new space with an unknown person who is interacting with them, so it is important to take into account that the first two sessions must have as an objective that participants feel motivated to perform the activity, feel safe towards the researcher and feel comfortable using the tablet, since it is the main tool that will be used to visualize the AR content.

Finally, referring to the objectives of the study, it can be indicated that the general objective which is to promote the inclusion of Augmented Reality as an intervention tool in the teaching-learning with people with Autism Spectrum Disorder is demonstrated throughout the work. This is due to the fact that after carrying out the search procedure of the articles about the learning style of the ASD participants, as well as the potentiality of the ICT tools in the development of the teaching processes and more specifically, of the Augmented Reality in these people, it is proved that it can be very useful as a teaching methodology. In later studies, after applying the specific objective of this work which is to create a protocol of activities, it will be possible to calculate in a quantitative way the achievement of learning.

\section{References}

American Psychiatric Association. (2013). Diagnostic and statistical manual of mental disorders, 5th edn. Arington, VA: American Psychiatric Publishing.

Badillo-Jiménez, V. T., \& Iguarán-Jiménez, A. M. (2020). Uso de las TIC en la enseñanza-aprendizaje de la comprensión lectora en niños autistas. Praxis, $16(1)$. doi: https://doi.org/10.21676/23897856.3406 
Booth. T \& Ainscow, M. (2002). Index for inclusion: Developing learning and participation in schools. Bristol, United Kingdom: Centre for Studies on Inclusive Education (CSIE).

Cabero, J. (2015). Reflexiones educativas sobre las tecnolog as de la informaci n y la comunicaci $\mathrm{n}$ (TIC). Tecnolog a, Ciencia y Educaci n, 1, 19-27.

Cruz, D., \& Villanueva, R. (2020). Importancia del trato en la escuela como factor terapéutico en casos TEA. Temas del psicoanálisis, 19.

El-Seoud, M., Halabi, O., \& Geroimenko, V. (2019). Assisting Individuals with Autism and Cognitive Disorders: An Augmented Reality based Framework. International Journal of Online Engineering, 15(4), 28-39.

Estebanell, M., Ferr s, J., Cornell , P. y Codina, D. (2012). Realidad aumentada y c digos QR en educaci n. In J. Hern ndez, M. Pennesi, D. Sobrino y A. V zquez (Coords.), Tendencias emergentes en educaci $n$ con TIC (pp. 135- 155). Barcelona, España: Asociaci n Espiral, Educaci n y Tecnolog a.

Gilabert, A., Pérez, E., Lorenzo, A., Lledó, A., \& Lorenzo, G. (2019). La realidad aumentada en la intervención del alumnado con trastorno del espectro autista a través de la producción científica. Revista INFAD de Psicología. International Journal of Developmental and Educational Psychology, 3(1), 595-606. doi: https://doi.org/10.17060/ijodaep.2019.n1.v3.1639

Hobson, P. (1995). El autismo y el Desarrollo de la Mente. Madrid, España: Editorial Alianza.

López García, A., \& Maquilón Sánchez, J. J. (2020, March). Diseño y aplicación de una propuesta de enseñanza mediada con realidad aumentada. Proceedings of the IV Congreso Internacional de Investigación e innovación en educación infantil y primaria, España.

Marín-Díaz, V. (2018). La Realidad Aumentada al servicio de la Inclusión educativa Estudio de caso [Augmented Reality in the service of educational inclusion. Case study]. Revista Retos XXI, 2 , 60-72. doi: https://doi.org/10.33412/retoxxi.v2.1.20600

Marín-Díaz, V., \& Sampedro-Requena, B. E. (2020). La Realidad Aumentada en Educación Primaria desde la visión de los estudiantes. ALTERIDAD. Revista de Educación, 15(1), 61-73. doi: http://dx.doi.org/10.17163/alt.v15n1.2020.05

Martínez, J. L., Pagán, F. J.B., García, S. A., \& Máiquez, M.C. C. (2014). Las tecnologías de la información y comunicación (TIC) en el proceso de enseñanza y aprendizaje del alumnado con trastorno del espectro autista (TEA). Revista Fuentes, (14), 193-208.

Miranda, M. J. V., Laz, E. M. S. A., \& Campuzano, M. F. P. (2020). Inclusión y su importancia en las instituciones educativas desde los mecanismos de integración del alumnado. Revista Arbitrada Interdisciplinaria Koinonía, 5(9), 5-27. doi: http://dx.doi.org/10.35381/r.k.v5i9.554

Reinoso, R. (2012). Posibilidades de la realidad aumentada en educaci n. In J. Hern ndez, M. Pennesi, D. Sobrino y A. V zquez (Coords.), Tendencias emergentes en educaci n con TIC (pp. 175-195). Barcelona, España: Asociaci n Espiral, Educaci n y Tecnolog a.

Riviere, A. (1998). El tratamiento del autismo como trastorno del desarrollo: principios generales. En A. Riviere y J. Martos (Coord.) El tratamiento del autismo. Nuevas perspectivas, (pp.23-60). Madrid, España: Asociación de Padres de Personas con Autismo (APNA) e Instituto de Migraciones y Servicios Sociales (IMSERSO).

V rtiz-Osores, R. I., P rez-Saavedra, S., Faustino-Sánchez, M. A., V rtiz-Osores, J. J., \& Alain, L. (2019). Tecnolog a de la Informaci $n$ y Comunicaci $n$ en estudiantes del nivel primario en el marco de la educaci $\mathrm{n}$ inclusiva en un Centro de Educaci $\mathrm{n}$ B sica Especial. Prop sitos y Representaciones, 7(1), 83-94. doi: http://dx.doi.org/10.20511/pyr2019.v7n1.266

Villalustre Mart nez, L. (2020). Propuesta metodol gica para la interaci n did ctica de la realidad aumentada en Educaci n Infantil. EDMETIC, Revista de Educaci $n$ Medi tica y TIC, 9(1), 170-187. doi: https://doi.org/10.21071/edmetic.v9i1.11569

Villanueva, R. y Brun, J. M. (2008), Projecte AGIRA (Assist ncia Global a Infants amb Risc d'Autisme) in l'Atenci Preco . Desenvolupa, 29, 31-49. 